\title{
Interaction between primary and secondary metabolism in Streptomyces coelicolor A3(2): role of pyrroline-5-carboxylate dehydrogenase
}

\author{
D. Drummond S. Smith, $\nmid$ Nicholas J. Wood and David A. Hodgson
}

Author for correspondence: David A. Hodgson. Tel: +44 1203 523559. Fax : +44 1203523701.
e-mail: dm @ dna.bio.warwick.ac.uk

Department of Biological Sciences, University of Warwick, Coventry CV4 7AL, UK
The activity of the proline catabolic enzyme pyrroline-5-carboxylate dehydrogenase (EC 1.5.1.12) was induced up to threehundredfold by the addition of three hundred proline to the growth medium of the Gram-positive bacterium Streptomyces coelicolor A3(2). Rifampicin, an inhibitor of RNA polymerase activity, abolished induction, implying that regulation was at the level of activation of gene transcription. The enzyme was purified and SDS-PAGE of the highly purified enzyme preparation revealed a single subunit with $M_{r} \mathbf{6 8 0 0 0}$. A single band of protein, which also stained for enzyme activity, was observed after native gel electrophoresis. The $M_{r}$ of the enzyme was estimated to be approximately 265000 by native gel electrophoresis and approximately $\mathbf{3 0 5 0 0 0}$ by gel filtration, which indicated that the enzyme had a tetrameric quaternary structure. The apparent $K_{\mathrm{m}}$ for pyrroline-5-carboxylate was $109 \pm 7.3 \mu \mathrm{M}$, whilst that for NAD+ was $43.3 \pm 2.5 \mu \mathrm{M}$. Product inhibition by NADH (apparent $K_{1} 0.6 \mathrm{mM}$ ) was observed. The observed $V_{\max }$ was $22.0 \pm 1 \mathrm{~mol} \mathrm{~min}^{-1}(\mathrm{mg}$ protein)-1. Neither $1 \mathrm{nor} 5 \mathrm{mM}$ proline had any effect on enzyme activity, whilst glutamate was a very weak inhibitor.

Keywords: Streptomyces coelicolor A3(2), proline catabolism, pyrroline-5-carboxylate dehydrogenase

\section{INTRODUCTION}

Streptomycetes produce a very wide variety of secondary metabolites, many of which have important medical and veterinary applications, not least as antibiotics. A large proportion of these secondary metabolites are derived from amino acids. For example, proline is a precursor of undecylprodigiosin and related compounds (Wasserman et al., 1974). Undecylprodigiosin is one of a number of secondary metabolites produced by Streptomyces coelicolor A3(2), the genetically best-characterized streptomycete (Kieser et al., 1992). Undecylprodigiosin (also known as prodigiosin 25-C) is a red pigment and has limited antibacterial and anti-protist properties. It has also been shown to suppress a number of functions of the immune response (Tsuji et al., 1992). As part of a larger study aimed at understanding the role and control of secondary metabolism and the interaction between primary and

†Present address: Protein Engineering Department, Institute of Food Research - Reading Laboratory, Earley Gate, Whiteknights Road, Reading RG6 2EF, UK.

Abbreviation: P5C, pyrroline-5-carboxylate. secondary metabolism in streptomycetes, the metabolism of proline and the synthesis of undecylprodigiosin are being examined (Hood et al., 1992).

The biosynthetic pathway to proline comprises three enzymes. Glutamate kinase and $\gamma$-glutamyl phosphate reductase catalyse the formation of glutamate-4semialdehyde from glutamate. The semialdehyde cyclizes in a spontaneous Schiff's reaction to form pyrroline-5carboxylate (P5C), which is converted to proline by $\mathrm{P} 5 \mathrm{C}$ reductase. Proline catabolism is accomplished by a twoenzyme pathway. Proline oxidase (proline dehydrogenase) catalyses the formation of $\mathrm{P} 5 \mathrm{C}$ from proline. P5C is spontaneously hydrated to glutamate-4-semialdehyde, which is converted to glutamate by P5C dehydrogenase.

Streptomycetes are unusual, not only in their ability to synthesize a wide range of secondary metabolites but also in their apparent lack of regulation of amino acid metabolism gene expression (Hood et al., 1992). It is tempting to speculate that these two properties are somehow related. Proline biosynthetic enzymes were not repressed by addition of proline to a culture of $S$. coelicolor A3(2). In fact, there was a mild (twofold) stimulation of 
gene expression. These observations were made by monitoring the effects on promoter fusion constructs using the promoters of the proB (glutamate kinase) and pro $A$ ( $\gamma$-glutamyl phosphate reductase) genes and assaying the amount of $\mathrm{P} 5 \mathrm{C}$ reductase present in cultures supplemented or not supplemented with proline (Hood et al., 1992). Preliminary evidence indicated that the enzymes of proline catabolism were expressed to the same level in $S$. coelicolor $\mathrm{A} 3(2)$ in media lacking proline as in media containing it (Hood et al., 1992). However, data presented in this paper reveal that there is substantial induction by proline in early exponential phase cells. Mutations leading to loss of proline catabolic enzyme activities led to increases in the production of undecylprodigiosin. This raises the possibility that undecylprodigiosin biosynthesis is a potential intracellular sink for proline, in an organism that lacks genetic control of proline biosynthesis. We wish to discover to what extent, if any, proline catabolism is regulated at the enzyme level and as part of this study we have, for the first time, purified P5C dehydrogenase (EC 1.5.1.12) from a streptomycete and studied the effects of potential effectors of enzyme activity.

\section{METHODS}

Materials. Superdex $200(2.6 \times 60 \mathrm{~cm})$, phenyl-Superose HR $5 / 5$ and mono-Q HR $5 / 5$ columns were obtained from Pharmacia, as was DEAE-Fast Flow Sepharose. Dowex 50U$\mathrm{X} 8$ was from Bio-Rad. Precast gels and other materials for electrophoresis were obtained from Pharmacia. 5-Hydroxylysine hydrochloride was obtained from Calbiochem, NAD + and streptomycin sulphate from Sigma, and phenazine methosulphate and nitroblue tetrazolium from $\mathrm{BDH}$. P5C was synthesized as described by Meile \& Leisinger (1982).

Growth of S. coelicolor A3(2) cells and preparation of cellfree extracts. The cells used to study P5C dehydrogenase induction were grown in liquid minimal medium (Hodgson, 1982) with $0 \cdot 1 \%(\mathrm{v} / \mathrm{v})$ glycerol as carbon source and $2 \mathrm{~g}$ ammonium sulphate $1^{-1}$ as nitrogen source. The spores were germinated in $2 \times$ YT (Strauch et al., 1991) before washing and transfer to minimal medium with $1 \%(\mathrm{w} / \mathrm{v})$ carboxymethylcellulose as dispersant (C. Potter, unpublished observations) in flasks containing stainless steel springs as baffles. Growth was monitored as increase in $\mathrm{OD}_{450}$ with time (Hodgson, 1982).

Two batches of $S$. coelicolor A3(2) strain J800 (prototrophic, $\mathrm{SCP}^{-} \mathrm{SCP}^{+}$) were prepared by Glaxo Research and Development Ltd., Greenford, one in a $50 \mathrm{l}$ fermenter and the other in a 5001 fermenter. The cells were cultured at $30^{\circ} \mathrm{C}$ in YEME medium (Hopwood et al., 1985) and were harvested when the culture reached early stationary phase. Yields were 1.07 and $5.5 \mathrm{~kg}$ wet wt from 45 and 4501 YEME, respectively. The cell paste was washed with $50 \mathrm{mM}$ Tris/ $\mathrm{HCl}$ buffer, $\mathrm{pH} 7 \cdot 5$, and resuspended in $50 \mathrm{mM}$ Tris $/ \mathrm{HCl}$ buffer, $\mathrm{pH} 7 \cdot 5$, containing $1 \mathrm{mM}$ EDTA and $1 \mathrm{mM}$ DTT. A cell-free extract was prepared by sonication of a suspension containing approximately $125 \mathrm{~g}$ wet wt cells in approximately $50 \mathrm{ml}$ buffer and clarified by centrifugation at $20000 \mathrm{~g}$ for $30 \mathrm{~min}$. These cell-free extracts were used to purify P5C dehydrogenase.

Enzyme and substrate assays. P5C dehydrogenase activity was determined by monitoring the reduction in $\mathrm{NAD}^{+}$at $340 \mathrm{~nm}$ $\left(\varepsilon 6220 \mathrm{M}^{-1} \mathrm{~cm}^{-1}\right)$. Assays were performed at $30^{\circ} \mathrm{C}$ in $0 \cdot 1 \mathrm{M}$ Tris/ $\mathrm{HCl}$ buffer, $\mathrm{pH} 7.5$, and contained $0.5 \mathrm{mM} \mathrm{P5C}$ and $0.5 \mathrm{mM} \mathrm{NAD}{ }^{+}$. $\mathrm{NAD}^{+}$concentrations were determined from absorbance at $260 \mathrm{~nm}\left(\varepsilon 18000 \mathrm{M}^{-1} \mathrm{~cm}^{-1}\right)$ of a suitable dilution of stock solution. P5C concentration was determined enzymatically using either P5C dehydrogenase or P5C reductase. This procedure measures the concentration of the enzymatically reactive isomer of P5C (Williams \& Frank, 1975). The level of induction of $\mathrm{P} 5 \mathrm{C}$ dehydrogenase was calculated as the amount of de novo enzyme synthesized in relation to new protein made since induction using the formula:

$\frac{\left(\mathrm{x}_{\mathrm{f}}\right) \sigma_{\mathrm{f}}}{\left(\mathrm{x}_{\mathrm{f}}-\mathrm{x}_{\mathrm{i}}\right) \sigma_{\mathrm{i}}}-1$

where $\sigma_{\mathrm{i}}=$ initial specific activity, $\sigma_{\mathrm{f}}=$ final specific activity, $x_{i}=$ initial protein concentration of culture and $x_{f}=$ final protein concentration of culture. Kinetic parameters were measured in four separate experiments and induction of P5C dehydrogenase by proline was assayed in detail on three occasions. Representative results are presented.

Purification of P5C dehydrogenase. Enzyme purification was performed on three occasions. A representative purification is presented below.

Step 1: Removal of nucleic acids etc. Streptomycin sulphate was added to clarified cell-free extract (protein concentration approximately $8 \mathrm{mg} \mathrm{ml}^{-1}$ ) to a final concentration of $2 \%(\mathrm{w} / \mathrm{v})$. The resulting solution was stirred at $4{ }^{\circ} \mathrm{C}$ for $30 \mathrm{~min}$ and the precipitate removed by centrifugation at $20000 \mathrm{~g}$ for $30 \mathrm{~min}$.

Step 2: DEAE-Sepharose chromatography. The supernatant was applied to a column of DEAE-Sepharose Fast Flow $(2.6 \times 13 \mathrm{~cm})$ which had been pre-equilibrated with $50 \mathrm{mM}$ Tris $/ \mathrm{HCl}, \mathrm{pH} 7 \cdot 5$, containing $10 \%$ glycerol, $1 \mathrm{mM}$ EDTA, $1 \mathrm{mM}$ DT'T and $0 \cdot 1 \mathrm{M} \mathrm{NaCl}$ (buffer A). After sample application, the column was washed with a further $110 \mathrm{ml}$ buffer $A$ and then developed with a $510 \mathrm{ml}$ linear $\mathrm{NaCl}$ gradient $(0 \cdot 1-0.5 \mathrm{M})$. The column was operated at $6 \mathrm{ml} \mathrm{min}-1$ and $8 \mathrm{ml}$ fractions were collected. Fractions containing P5C dehydrogenase activity, which eluted as a single peak around $0.33 \mathrm{M}$ $\mathrm{NaCl}$, were pooled and concentrated by ultrafiltration to a volume of approximately $13 \mathrm{ml}$.

Step 3: Superdex 200 chromatography. Pooled, concentrated fractions from ion-exchange columns were applied in two equal volumes to a Superdex $200(2.6 \times 60 \mathrm{~cm})$ gel filtration column pre-equilibrated with buffer $A$. The column was developed using the same buffer at a flow rate of $3 \mathrm{ml} \mathrm{min}^{-1}$ and the eluate was collected in $4 \mathrm{ml}$ fractions. Fractions from both runs containing $\mathrm{P} 5 \mathrm{C}$ dehydrogenase, which eluted in a single peak centred at $148 \mathrm{ml}$ elution volume, were pooled.

Step 4: Mono-Q chromatography. The P5C dehydrogenase sample obtained after gel filtration chromatography was subjected to ion-exchange chromatography on a mono-Q HR 5/5 column. The column was equilibrated using buffer $A$ and after sample application was washed with a further $25 \mathrm{ml}$ buffer $\mathrm{A}$ followed by $2 \mathrm{ml}$ of the same buffer containing $0 \cdot 2 \mathrm{M} \mathrm{NaCl}$. A linear $\mathrm{NaCl}$ gradient $(0 \cdot 2-0 \cdot 55 \mathrm{M})$ of total volume $50 \mathrm{ml}$ was then applied to the column. All operations were performed at a flow rate of $2 \mathrm{ml} \mathrm{min}^{-1}$ and $2 \mathrm{ml}$ fractions were collected. P5C dehydrogenase eluted in a single peak at $0.36 \mathrm{M} \mathrm{NaCl}$ and the active fractions were pooled.

Step 5: Hydrophobic interaction chromatography. The P5C dehydrogenase fraction from the mono-Q column was prepared for hydrophobic interaction chromatography (HIC) by the addition of sufficient $0.1 \mathrm{M}$ Tris/ $\mathrm{HCl}$ buffer, $\mathrm{pH} 7 \cdot 5$, containing $10 \%$ glycerol, $1 \mathrm{mM}$ EDTA, $1 \mathrm{mM}$ DTT and $2 \mathrm{M}\left(\mathrm{NH}_{4}\right)_{2} \mathrm{SO}_{4}$, to give a final $\left(\mathrm{NH}_{4}\right)_{2} \mathrm{SO}_{4}$ concentration of $1.4 \mathrm{M}$. The phenylSuperose HR $5 / 5$ column was equilibrated with $0 \cdot 1 \mathrm{M}$ Tris/ 
$\mathrm{HCl}, 10 \%$ glycerol, $1 \mathrm{mM}$ EDTA, $1 \mathrm{mM}$ DTT, $1.4 \mathrm{M}$ $\left(\mathrm{NH}_{4}\right)_{2} \mathrm{SO}_{4}, \mathrm{pH} 7 \cdot 5$, (buffer B) and was operated at $0.3 \mathrm{ml} \mathrm{min}^{-1}$ collecting $1 \mathrm{ml}$ fractions. After sample application the phenylSuperose column was washed with $20 \mathrm{ml}$ buffer B. The P5C dehydrogenase was eluted using a linear gradient of $\left(\mathrm{NH}_{4}\right)_{2} \mathrm{SO}_{4}$ $(1.40 \mathrm{M})$ of total volume $30 \mathrm{ml}$. Enzyme activity eluted at an $\left(\mathrm{NH}_{4}\right)_{2} \mathrm{SO}_{4}$ concentration of approximately $0.6 \mathrm{M}$ and could be stored in this buffer at $4{ }^{\circ} \mathrm{C}$ with little loss of activity after several weeks.

Polyacrylamide gel electrophoresis. Electrophoresis experiments were performed using the 'PhastSystem' apparatus (Pharmacia). Electrophoresis in the presence of SDS was carried out using 10-15\% gradient gels ('Phastgel 10-15') for $65 \mathrm{~V} \mathrm{~h}$ and were stained using Coomassie blue as recommended by the manufacturer. Gel electrophoresis in the absence of SDS was performed using 8-22\% gradient gels ('Phastgel 8-22') for $300 \mathrm{~V} \mathrm{~h}$ at $10^{\circ} \mathrm{C}$. Non-denaturing gels were stained either for protein or for enzyme activity. P5C dehydrogenase activity was detected in native gels by incubating the gel in the dark in $0.1 \mathrm{M}$ Tris buffer, $\mathrm{pH} 7.5$, containing $0.2 \mathrm{mM}$ P5C, $0.2 \mathrm{mM} \mathrm{NAD}^{+}$, $0.003 \mathrm{mg}$ phenazine methosulphate $\mathrm{ml}^{-1}$ and $0.6 \mathrm{mg}$ nitroblue tetrazolium ml $\mathrm{m}^{-1}$. After development the gels were washed with $10 \%(\mathrm{v} / \mathrm{v})$ acetic acid containing $10 \%$ glycerol and dried for storage.

\section{RESULTS AND DISCUSSION}

\section{Induction of P5C dehydrogenase activity}

Previous data (Hood et al., 1992) appeared to show that P5C dehydrogenase was a constitutive enzyme. A specific activity of $30 \cdot 3$ units (g protein) ${ }^{-1}$ was obtained from cells grown on a cellophane disk on solid minimal medium containing ammonium as sole nitrogen source and one of 27.7 units (g protein $)^{-1}$ from cells grown on proline as sole nitrogen source. Further work in our laboratory revealed that if young cultures were used (no evidence of aerial hyphae), then a very much lower specific activity of P5C dehydrogenase was obtained from cells grown on ammonium as sole nitrogen source and a very much higher specific activity from cells grown on proline as sole nitrogen source. If older cultures were used (aerial hyphae present), then the specific activities from cells grown under the two conditions were closer, although prolinegrown cells still showed higher activity (C. West, unpublished observations).

The kinetics of induction of $\mathrm{P} 5 \mathrm{C}$ dehydrogenase was examined in cells growing on ammonium as sole nitrogen source and glycerol as sole carbon source. In midexponential phase a sample was taken before addition of $3.5 \mathrm{mM}$ proline to the culture. Further samples were taken at hourly intervals. The samples were assayed for P5C dehydrogenase activity and the results are plotted with the growth curve in Fig. 1(a). The activity of the enzyme in cells before addition of proline was 4.7 units ( $g$ protein $)^{-1}$. Three hours after addition of proline the activity reached a maximum of 127 units $(\mathrm{g} \text { protein })^{-1}$ (123-fold induction).

The induction of P5C dehydrogenase could be due to induction of gene transcription, induction of gene translation and/or activation of enzyme function in an inactive
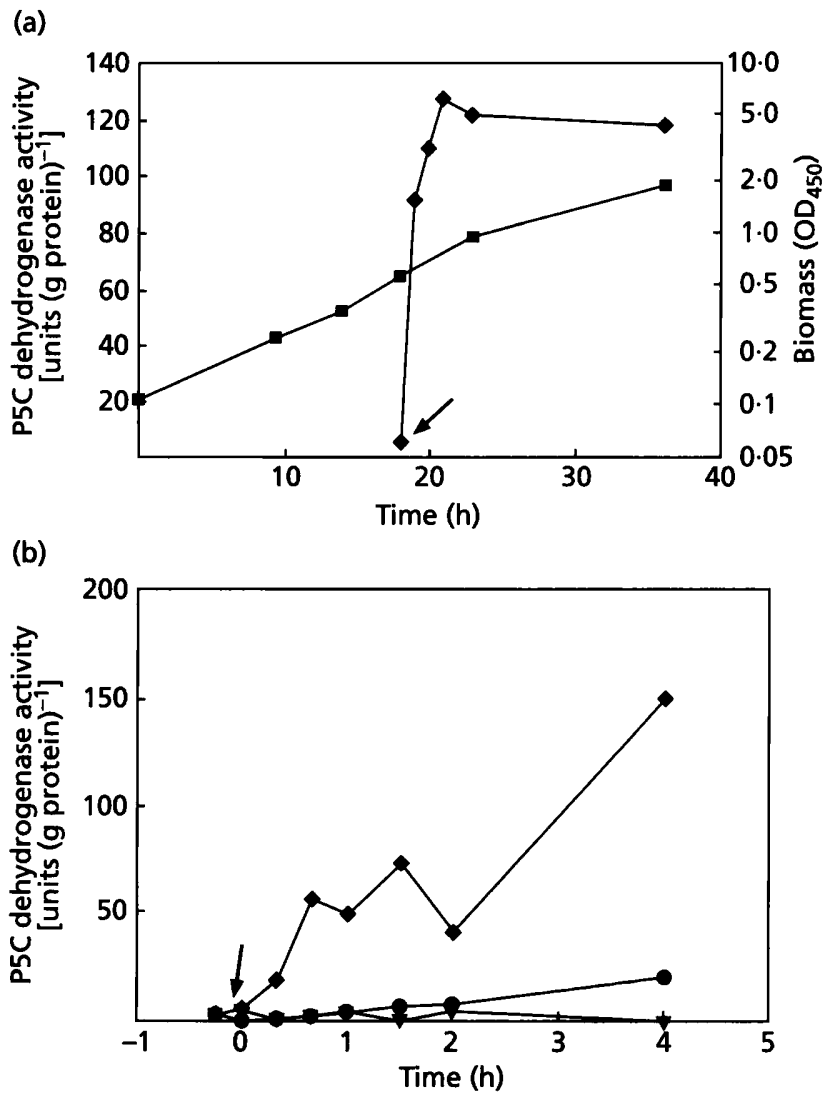

Fig. 1. Induction of P5C dehydrogenase activity. (a) Kinetics of induction of P5C dehydrogenase. P5C dehydrogenase specific activity $(\diamond)$ and accumulation of biomass $(\square)$ after addition of $3.5 \mathrm{mM}$ proline at arrow. (b) Inhibition of P5C dehydrogenase activity induction by chloramphenicol and rifampicin. P5C dehydrogenase specific activity in the presence of $50 \mu \mathrm{g}$ chloramphenicol $\mathrm{ml}^{-1}(\nabla), 100 \mu \mathrm{g}$ rifampicin $\mathrm{ml}^{-1}(0)$ and no drug $(\diamond)$. The arrow indicates the point of addition of $3.5 \mathrm{mM}$ proline.

peptide. To examine at what point regulation occurred, the induction of $\mathrm{P} 5 \mathrm{C}$ dehydrogenase activity was examined in the presence of rifampicin, an inhibitor of transcription, and chloramphenicol, an inhibitor of translation. Mid-exponential cells were sampled, then treated with $100 \mu \mathrm{g}$ rifampicin $\mathrm{ml}^{-1}, 50 \mu \mathrm{g}$ chloramphenicol ml${ }^{-1}$ or drug solvent $[50 \%(\mathrm{v} / \mathrm{v})$ ethanol], for $15 \mathrm{~min}$ before addition of proline and further sampling over $4 \mathrm{~h}$. The samples were assayed for P5C dehydrogenase activity (Fig. 1b). In the untreated control the activity of P5C dehydrogenase rose from 3 to 151 units (g protein) ${ }^{-1}$ over $4 \mathrm{~h}$ (317-fold induction). However, there was no induction of activity in chloramphenicol-treated cells and greatly reduced induction in the presence of rifampicin. The observation that both inhibitors prevented induction demonstrates that enzyme activation is not the mechanism of induction. Inhibition by the RNA polymerase inhibitor rifampicin suggests that proline induction of P5C dehydrogenase activity occurred at the level of gene transcription. 
Table 1. Purification of $\mathrm{P} 5 \mathrm{C}$ dehydrogenase

\begin{tabular}{|lccccc|}
\hline Step & $\begin{array}{c}\text { Total } \\
\text { activity } \\
\text { (units) }\end{array}$ & $\begin{array}{c}\text { Total } \\
\text { protein } \\
\text { (mg) }\end{array}$ & $\begin{array}{c}\text { Specific } \\
\text { activity } \\
\text { [units (mg } \\
\text { protein) }\end{array}$ & $\begin{array}{c}\text { Yield } \\
\text { (\%) }\end{array}$ & $\begin{array}{c}\text { Purification } \\
\text { (-fold) }\end{array}$ \\
\hline Crude extract & 182 & 8400 & $0 \cdot 022$ & 100 & \\
Streptomycin supernatant & 157 & 6600 & $0 \cdot 024$ & 86 & 1 \\
DEAE pool & 191 & 456 & $0 \cdot 42$ & 105 & 19 \\
Superdex 200 pool & 116 & $32 \cdot 1$ & $3 \cdot 6$ & 64 & 164 \\
Mono-Q pool & 70 & $3 \cdot 2$ & $21 \cdot 8$ & 38 & 990 \\
HIC pool & 66 & 3 & 22 & 36 & 1000 \\
\hline
\end{tabular}

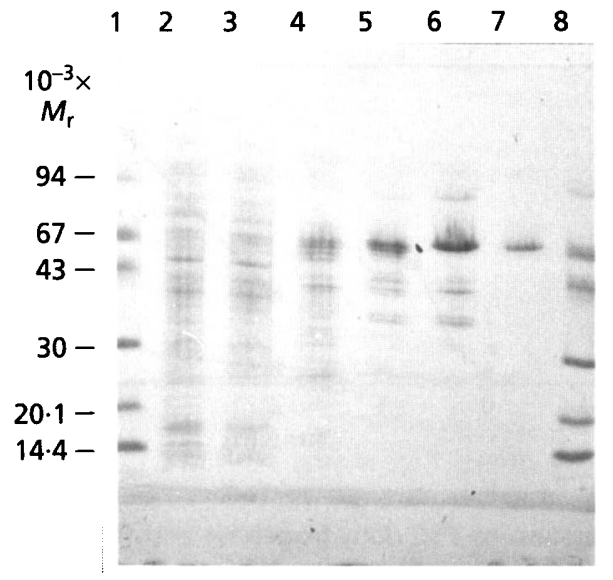

Fig. 2. SDS-PAGE of fractions obtained during the purification of P5C dehydrogenase. Tracks: 1 and $8, M_{r}$ size markers (phosphorylase b, 94000; BSA, 67000; ovalbumin, 43000; carbonic anhydrase, 30000; soya bean trypsin inhibitor, 20100; $\alpha$-lactalbumin, 14400); 2 , crude cell extract; 3 , streptomycin sulphate pool; 4, pool after DEAE-Sepharose chromatography; 5, pool after Superdex 200 chromatography; 6, pool after mono-Q chromatography; 7, purified $\mathrm{P} 5 \mathrm{C}$ dehydrogenase after phenyl-Superose chromatography.

\section{Enzyme purification and subunit structure}

No proline was added to the YEME medium used to produce biomass for enzyme purification. However, it is clear that there was enough of the imino acid present in this complex medium to induce expression of the enzyme (Table 1). Purification of P5C dehydrogenase using a combination of ion-exchange, gel filtration and hydrophobic interaction chromatographies yielded $3 \mathrm{mg}$ pure protein after a 1000 -fold purification with $36 \%$ yield (Table 1). The first ion-exchange (DEAE-Sepharose) step not only resulted in good purification but also separated the $\mathrm{P} 5 \mathrm{C}$ dehydrogenase and $\mathrm{P} 5 \mathrm{C}$ reductase activities, both of which could be subsequently purified. After further purification by gel filtration and ion-exchange (mono-Q) chromatography P5C dehydrogenase was substantially pure, only minor contaminants being detected during SDS-PAGE. Homogeneous enzyme free of impurities

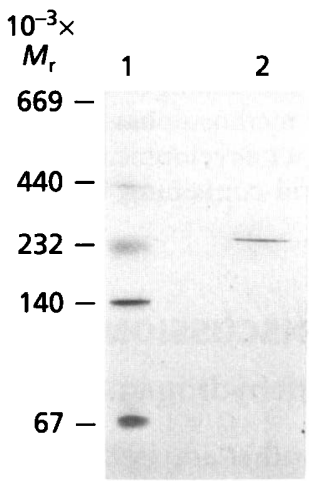

Fig. 3. Non-denaturing PAGE of P5C dehydrogenase. Tracks: 1 , size markers (thyroglobulin, 669000; ferritin, 440000; catalase, 232000; lactate dehydrogenase, 140000; BSA, 67000); 2, purified P5C dehydrogenase.

was obtained after hydrophobic interaction chromatography on phenyl-Superose.

A sample of protein after SDS-PAGE was subjected to Nterminal sequence analysis. however, no sequence information was found, implying the $\mathrm{N}$-terminus of the protein was blocked. After digestion using Staphylococcus aureus V8 protease, sequence information was obtained from one of the peptides.

SDS-PAGE of purified P5C dehydrogenase showed a single polypeptide with an $M_{\mathrm{r}}$ of 68000 (Fig. 2). This is similar to the subunit $M_{\mathrm{r}}$ of the monofunctional P5C dehydrogenases purified from other sources (Isobe $e t$ al., 1987; Small \& Jones, 1990; Farres et al., 1988). Gel filtration chromatography yielded an $M_{\mathrm{r}}$ for the native enzyme of around 305000 . Combining the estimates of the $M_{\mathrm{r}}$ of the native enzyme with that of the subunits obtained by SDS-PAGE suggests that the $S$. coelicolor P5C dehydrogenase is a tetramer. Non-denaturing gel electrophoresis showed a single protein band to be present in the dehydrogenase preparation (Fig. 3). When native gels were stained to detect $\mathrm{P} 5 \mathrm{C}$ dehydrogenase activity a single band of activity was detected which co-electrophoresed with the single protein band strongly supporting identi- 
fication of this protein as P5C dehydrogenase. Comparison of the migration of the $\mathrm{P} 5 \mathrm{C}$ dehydrogenase band with a number of standard proteins gave an estimate for the native $M_{\mathrm{r}}$ of the dehydrogenase of 265000 . This further supports the tetrameric quaternary structure determined by gel filtration chromatography.

The P5C dehydrogenase enzymes isolated from other sources (Isobe et al., 1987; Small \& Jones, 1990; Farres et al., 1988) were dimers, although a monomeric form of the Salmonella typhimurium enzyme (Menzel \& Roth, 1981) and a tetrameric form of the Pseudomonas aeruginosa enzyme (Meile \& Leisinger, 1982) were observed. The $P$. aeruginosa and S. typhimurium $\mathrm{P} 5 \mathrm{C}$ dehydrogenase activities are both associated with bifunctional polypeptides which also show proline oxidase activity. The proline oxidase activity of $S$. coelicolor $\mathrm{A} 3(2)$ is associated with the membrane fraction of the cell and is readily separable from the cytoplasmic P5C dehydrogenase activity (Hood et al., 1992). It appears, therefore, that the streptomycete enzyme is more similar to the Bacillus sphaericus enzyme in this respect although it is larger (68000 compared to 50000 ) and tetrameric rather than dimeric (Isobe et al., 1987).

\section{Kinetic properties}

Kinetic studies of the enzymic reaction gave apparent $K_{\mathrm{m}}$ values for P5C and for $\mathrm{NAD}^{+}$of $109 \pm 7 \cdot 3$ and $43.3 \pm 2.5 \mu \mathrm{M}$, respectively, with a $V_{\max }$ of $22.0 \pm 1 \mu \mathrm{mol} \mathrm{min}^{-1}$ (mg protein) $)^{-1}$. Assuming a single active site per subunit this corresponds to a $k_{\text {cat }}$ value of $25 \mathrm{~s}^{-1}$ with a value of $k_{\text {cat }} / K_{\mathrm{m}}$ for P5C of $2.94 \times 10^{5} \mathrm{M}^{-1} \mathrm{~s}^{-1}$. Proline did not affect the rate of reaction. Glutamate was only very weakly inhibitory, around $30 \%$ inhibition being observed at $25 \mathrm{mM}$ glutamate. Product inhibition by NADH was observed which was competitive both with P5C $\left(K_{\mathbf{i}} 770 \mu \mathrm{M}\right)$ and $\mathrm{NAD}^{+}\left(K_{\mathrm{i}} 600 \mu \mathrm{M}\right)$.

\section{The role of P5C dehydrogenase in secondary metabolism}

The kinetic data reveal the lack of any regulation of enzyme activity beyond feedback inhibition by the two products NADH and glutamate. The lack of allosteric regulation by proline means we cannot evoke a mechanism of direct regulation at the enzyme level of proline catabolism as a means of controlling proline flux within the $S$. coelicolor A3(2) cell. Therefore, we are still left with the question as to how the cell regulates the flow of proline into primary metabolism, i.e. protein biosynthesis and proline catabolism, and secondary metabolism, i.e. undecylprodigiosin biosynthesis. When the cell ceases to grow and protein synthesis diminishes, proline will accumulate because the imino acid is synthesized constitutively due to the lack of feedback repression of biosynthesis (Hood et al., 1992). This excess proline should lead to induction of proline catabolism genes and hence futile cycling of proline. If proline catabolism is not possible, because of a genetic lesion for example, proline will be shunted exclusively into undecylprodigiosin biosynthesis (Hood et al., 1992).

Under normal conditions, i.e. when proline catabolism is possible, the surplus proline necessary for conversion into undecylprodigiosin could arise by a number of mechanisms. Proline biosynthesis could overwhelm proline catabolism; there might be a mechanism by which induction of the proline catabolism genes is reduced or halted during secondary metabolism; and/or if glutamate or $\mathrm{NADH}$ accumulated in the cell this could cause feedback inhibition of P5C dehydrogenase and consequent feedback inhibition of proline oxidase by the resultant $\mathrm{P} 5 \mathrm{C}$ or glutamate-4-semialdehyde accumulation. Once we have cloned the gene encoding P5C dehydrogenase using the sequence information we have obtained from this work, we will be able to test if expression of the gene is co-ordinated with undecylprodigiosin biosynthesis. Purification and studies of the kinetic properties of other proline metabolic enzymes are also in hand.

\section{ACKNOWLEDGEMENTS}

We would like to thank Mrs Leslie Ward for excellent technical assistance and Dr Brian A. M. Rudd of Glaxo Research \& Development Ltd. for preparation of S. coelicolor A3(2) biomass. This work was supported by the 'Secondary Metabolism of Streptomyces' initiative funded in part by Glaxo and SmithKline Beecham.

\section{REFERENCES}

Farres, J., Julia, P. and Pares, X. (1988). Aldehyde oxidation in human placenta: purification and properties of 1-pyrroline-5carboxylate dehydrogenase. Biochem J 256, 461-467.

Hodgson, D. A. (1982). Glucose repression of carbon source uptake and metabolism in Streptomyces coelicolor A3(2) and its perturbation in mutants resistant to 2-deoxyglucose. J Gen Microbiol 128, 2417-2430.

Hood, D. W., Heidstra, R., Swoboda, U. K. \& Hodgson, D. A. (1992). Molecular genetic analysis of proline and tryptophan biosynthesis in Streptomyces coelicolor A3(2): interaction between primary and secondary metabolism - a review. Gene 115, 5-12.

Hopwood, D. A., Bibb, M. J., Chater, K. F., Kieser, T., Bruton, C. P., Kieser, H. M., Lydiate, D. J., Smith C. P., Ward, J. M. \& Schrempf, H. (1985). Genetic Manipulation of Streptomyces: a Laboratory Manual. Norwich: The John Innes Foundation.

Isobe, K., Matsuzawa, T. \& Soda, K. (1987). Crystallization and characterization of the 1-pyrroline-5-carboxylate dehydrogenase from Bacillus sphaericus. Agric Biol Chem 51, 1947-1953.

Kieser, H. M., Kieser, T. \& Hopwood, D. A. (1992). A combined genetic and physical map of the Streptomyces coelicolor A3(2) chromosome. J Bacteriol 174, 5496-5507.

Meile, L. \& Leisinger, T. (1982). Purification and properties of the bifunctional proline dehydrogenase 1-pyrroline-5-carboxylate dehydrogenase from Pseudomonas aeruginosa. Eur J Biochem 129, 67-75.

Menzel, R. \& Roth, J. (1981). Purification of the $p u t A$ gene product: a bifunctional, membrane bound protein from Salmonella typhimurium responsible for the 2-step oxidation of proline to glutamate. J Biol Chem 256, 9755-9761.

Small, W. C. \& Jones, M. E. (1990). Pyrroline-5-carboxylate dehydrogenase of the mitochondrial matrix of rat liver: purification, physical and kinetic characteristics. J Biol Chem 265, 18668-18672. 
Strauch, E., Takano, E., Baylis, H. A. \& Bibb, M. J. (1991). The stringent response in Streptomyces coelicolor A3(2). Mol Microbiol 5, 289-298.

Tsuji, R. F., Magae, J., Yamashita, M., Nagai, K., \& Yamasaki, M. (1992). Selective immunosuppression of prodigiosin $25 \mathrm{C}$ and FK506 in the murine immune system. $J$ Antibiot 45, 1295-1302.

Wasserman, H. H., Shaw, C. K., Sykes, R. J., \& Cushley, R. J.
(1974). The biosynthesis of metacycloprodigiosin and undecylprodigiosin. Tetrabedron Lett 33, 2787-2790.

Williams, I. \& Frank, L. (1975). Improved chemical synthesis and enzymatic assay of $\Delta-1$-pyrroline-5-carboxylic acid. Anal Biochem 64, 85-97.

Received 9 January 1995; revised 31 March 1995; accepted 10 April 1995. 